\title{
A rapid and highly specific technique to detect hepatitis C RNA in frozen sections of liver
}

\author{
C Sergi, T Goeser, G Otto, H F Otto, W J Hofmann
}

\begin{abstract}
Aims-To develop a polymerase chain reaction (PCR) based technique that would permit the rapid and highly specific detection of hepatitis C virus (HCV) RNA extracted from frozen liver tissue.

Methods-Samples of liver tissue from 18 patients undergoing orthotopic liver transplantation were studied. Nine patients were HCV positive. Total RNA was extracted from between one and 10 sections, $10 \mu \mathrm{m}$ thick, from each tissue sample. HCV RNA was amplified by (1) conventional, multistep reverse transcription PCR (RT-PCR) and by (2) combined, single step RT-PCR using coupled oligonucleotide primers based on the sequence of the $5^{\prime}$ untranslated region of the viral genome. Positive results were confirmed by dot blot analysis using a digoxigenin labelled oligoprobe (Alx 89).

Results-HCV RNA was detected in the nine HCV positive patients by both conventional and combined RT-PCR. HCV RNA was not detected in the HCV negative patients. As little as $\mathbf{5 0 0}$ ng total RNA was needed as the template to yield detectable amounts of amplified cDNA. The digoxigenin labelled oligoprobe hybridised with HCV RNA positive specimens only. Conclusions-The combined, single step RT-PCR is a rapid and sensitive technique for detecting HCV RNA in frozen liver tissue.
\end{abstract}

(f Clin Pathol 1996;49:369-372)

Presented in part at the 79 th Meeting of the German Society of Pathology, 6-10 June, 1995 (Pathol Res Pract 1995;191:229).

Department of

Pathology,

University of

Heidelberg,

Heidelberg, Germany

C Sergi

H F Otto

W J Hofmann

Department of Internal Medicine $\mathrm{T}$ Goeser

Department of Surgery

G Otto

Correspondence to: Dr W J Hofmann, Department of Pathology, University of Heidelberg, Im Neuenheimer Feld 220/221,

D-69120 Heidelberg,

Germany.

Accepted for publication

16 January 1996
Keywords: liver, orthotopic liver transplantation, hepatitis $\mathrm{C}$ virus, RNA, PCR.

The polymerase chain reaction (PCR) is now widely used to amplify DNA and RNA. ${ }^{1}$ Detection of RNA is more difficult than that of genomic DNA mainly because of the presence of contaminating RNases; the presence of DNA molecules after extraction of RNA may also complicate reverse transcription (RT). Contamination of the laboratory with trace amounts of amplicons can compromise later PCR reamplified in turn. To limit contamination, reverse transcription and PCR are carried out in the same tube. To date, combined PCR techniques for detecting HCV RNA have been described only for serum samples, ${ }^{23}$ and not for samples of liver tissue, which generally have a higher viral load. actions when these trace contaminants are

\section{Methods}

Samples of liver tissue were obtained from 18 patients undergoing orthotopic liver transplantation. Nine patients were $\mathrm{HCV}$ positive. The indication for transplantation was hepatocellular carcinoma and liver cirrhosis in 10 patients, fulminant or subacute hepatitis in five, and liver cirrhosis in three. Samples of liver tissue were sectioned within minutes of being removed, snap frozen and stored at $-80^{\circ} \mathrm{C}$.

\section{PRIMERS}

The following sets of primers from the $5^{\prime}$ untranslated region of the viral genome were used to amplify the HCV RNA ${ }^{45}$ : HepCV 29 (outer antisense): 5'-GGA ACT TGA CGT CCT GTG GGC-3'; HepCV 28 (outer sense): 5'TGG GGG CGA CAC ATC CAC CAT-3'; HepCV 24 (inner antisense): 5'-GTG CTC ATG GTG CAC GGT CTA CGA-3'; and HepCV 23 (inner sense): 5'-TGT CTT CAC GCA GAA AGC GTC TAG-3'. The expected PCR products using these primers are 394 base pairs (bp) and $298 \mathrm{bp}$, respectively. The HepCV 29 antisense primer was also used for gene priming specific reverse transcription in both RT-PCR methods. The primers and oligoprobe were made using an Applied Biosystems DNA synthesiser.

\section{EXTRACTION OF RNA}

Total RNA was extracted from between one and 10 frozen sections, $10 \mu \mathrm{m}$ thick, using a modified acid guanidinium phenol/chloroform method. ${ }^{6}$ Briefly, tissue sections were scraped and incubated for a few minutes with $0.5 \mathrm{ml}$ diethylpyrocarbonate (DEPC) treated water, containing $4 \mathrm{M}$ guanidinium thiocyanate, $25 \mathrm{mM}$ sodium citrate, $0.2 \mathrm{M} \beta$-mercaptoethanol, and $2 \mathrm{M}$ sodium acetate; $500 \mu \mathrm{l}$ water saturated phenol and $100 \mu \mathrm{l}$ chloroform: isoamyl alcohol (24:1) were then added. The solution was mixed with isopropanol $(1: 1)$, resulting in sedimentation of RNA. The RNA pellet was then resuspended in ethanol, sedimented, dried in a vacuum, and dissolved in 15-30 $\mu 1$ DEPC treated water.

\section{CONVENTIONAL CDNA SYNTHESIS AND PCR}

Gene specific priming reverse transcription was carried out in $0.5 \mathrm{ml}$ microtubes containing $4 \mu \mathrm{l}$ buffer (250 mM Tris- $\mathrm{HCl}$ (pH 8.3), $375 \mathrm{mM}$ $\mathrm{KCl}, 15 \mathrm{mM} \mathrm{mgCl}_{2}$ ), $0.8 \mu$ of $100 \mathrm{mM}$ dNTPs (dATP, dCTP, dGTP, dTTP), $1 \mu \mathrm{l}$ of $25 \mu \mathrm{M}$ antisense adapter primer (HepCV 29), 0.75 $\mu \mathrm{l}$ RNasin (40 U/ $\mu \mathrm{l}$; Promega, Madison, Wis- 
Table 1 Comparison of the clinical and serum laboratory findings with RT-PCR

\begin{tabular}{|c|c|c|c|c|c|c|c|}
\hline \multirow[b]{2}{*}{$\begin{array}{l}\text { Case } \\
\text { number }\end{array}$} & \multirow[b]{2}{*}{$\begin{array}{l}\text { OLT } \\
\text { number }\end{array}$} & \multirow[b]{2}{*}{ Disease } & \multicolumn{3}{|c|}{ Serum laboratory data } & \multicolumn{2}{|c|}{ Combined RT-PCR } \\
\hline & & & $\begin{array}{l}\text { Anti- } \\
H C V\end{array}$ & $\begin{array}{l}H C V- \\
R N A\end{array}$ & $\begin{array}{l}\text { Conventional } \\
R T-P C R\end{array}$ & $\begin{array}{l}\text { Alternative } \\
1\end{array}$ & $\begin{array}{l}\text { Alternative } \\
2\end{array}$ \\
\hline 1 & 17 & HCC, cirrhosis, HCV & + & + & + & + & + \\
\hline 2 & 19 & Fulminant hepatits & - & - & - & - & - \\
\hline 3 & 21 & Cirrhosis, HCV & + & + & + & + & + \\
\hline 4 & 29 & Subacute hepatitis & - & - & - & - & - \\
\hline 5 & 31 & HCC, cirrhosis, HBV & - & - & - & - & - \\
\hline 6 & 32 & HCC, cirrhosis, HCV & + & + & + & + & ND \\
\hline 7 & 38 & Fulminant hepatitis & - & - & - & - & - \\
\hline 8 & 39 & HCC, cirrhosis, HBV & - & - & - & - & - \\
\hline 9 & 43 & HCC, cirrhosis, ethylism & - & - & - & - & - \\
\hline 10 & 113 & HCC & - & - & - & - & - \\
\hline 11 & 114 & HCC, cirrhosis, HCV & + & + & + & + & + \\
\hline 12 & 115 & Subacute hepatitis & - & - & - & - & - \\
\hline 13 & 150 & HCC, cirrhosis, ethylism & - & - & - & - & - \\
\hline 14 & 161 & Cirrhosis, HCV, TIPS & + & + & + & + & + \\
\hline 15 & 163 & Subacute hepatitis & + & + & + & + & + \\
\hline 16 & 214 & HCC, cirrhosis, HCV & + & + & + & + & + \\
\hline 17 & 232 & Cirrhosis, ethylism, HCV & + & + & + & + & ND \\
\hline 18 & 239 & HCC, cirrhosis, HCV & + & + & + & + & ND \\
\hline
\end{tabular}

HCC = hepatocellular carcinoma; TIPS = transjugular intrahepatic portosystemic shunt; OLT = orthotopic liver transplant; ND = not determined.

consin, USA), $0 \cdot 5-2 \mu \mathrm{g}$ total RNA, and $2 \mu \mathrm{l}$ of $200 \mathrm{U} / \mu \mathrm{l}$ Superscript reverse transcriptase (Gibco BRL, Eggenstein, Germany) or $1 \mu \mathrm{l}$ of $500 \mathrm{U} / \mu \mathrm{l}$ AMV reverse transcriptase (Boehringer Mannheim, Mannheim, Germany) with a total volume of $20 \mu \mathrm{l}$. Samples were incubated at $42^{\circ} \mathrm{C}$ for one hour. Reverse transcriptase was then inactivated by heating the reaction mixture at $95^{\circ} \mathrm{C}$ for five minutes. Samples were kept on ice until amplification took place. For the first round of amplification (one minute at $93^{\circ} \mathrm{C}$, one minute at $45^{\circ} \mathrm{C}$ and one minute at $72^{\circ} \mathrm{C}$ ), $50 \mu \mathrm{l}$ of reaction mixture containing $10 \times$ PCR buffer $(100 \mathrm{mM}$ Tris- $\mathrm{HCl}, 500 \mathrm{mM}$ $\mathrm{KCl}, 1 \mathrm{~g} / \mathrm{l}$ gelatin, $\mathrm{pH} 8.3), 1.5 \mathrm{mM} \mathrm{MgCl}_{2}$, $10 \mathrm{mM}$ dNTPs, $25 \mu \mathrm{M}$ outer sense and antisense primers (HepCV 29 and HepCV 28), and $2 \mu \mathrm{l} \mathrm{cDNA}$ was placed in a Thermal Cycler (Perkin-Elmer Cetus Corp., Norwalk, Connecticut, USA). The "hot start" method was used in which cDNA and 2.5 units of Taq DNA polymerase (Perkin-Elmer) were separated from the primers by a layer of wax to prevent mispriming at lower temperatures. ${ }^{7}$ In the second round of amplification (one minute at $93^{\circ} \mathrm{C}$, one minute at $60^{\circ} \mathrm{C}$, one minute at $72^{\circ} \mathrm{C}$ for 30 cycles), $5-10 \%$ of the first PCR product was used as template. A $10 \mu \mathrm{l}$ aliquot of the nested PCR product was run on a $1 \%$ agarose gel stained with ethidium bromide. DNA molecular weight markers $\mathrm{V}$ and VI (Boehringer Mannheim) were used as molecular size markers.

\section{COMBINED CDNA SYNTHESIS AND PCR}

Between $500 \mathrm{ng}$ and $2 \mu \mathrm{g}$ of total RNA from each sample was placed in a $0.5 \mathrm{ml}$ microtube and kept at $4^{\circ} \mathrm{C}$. Then $1 \mu \mathrm{l}(25 \mu \mathrm{M})$ of the outer sense and antisense primers (HepCV 28 and HepCV 29) and $0.75 \mu \mathrm{l}$ RNasin (Promega) were added and the reaction mixture was incubated at $65^{\circ} \mathrm{C}$ for 15 minutes to destroy the secondary structure of the nucleic acid. To a total volume of $100 \mu \mathrm{l}$ of this RNA mixture, $10 \times$ PCR buffer $(100 \mathrm{mM}$ Tris- $\mathrm{HCl}, 500 \mathrm{mM}$ $\mathrm{KCl}, 1 \mathrm{~g} / \mathrm{l}$ gelatin, $\mathrm{pH} 8.3), 1.5 \mathrm{mM} \mathrm{MgCl}_{2}$, $10 \mathrm{mM} \mathrm{dNTPs}$, and $6 \cdot 25-7 \cdot 5 \mathrm{U} / \mu \mathrm{l}$ of AMV reverse transcriptase were added. At this point, either $25 \mu \mathrm{l}$ mineral oil or PrimeWax (Biometra, Göttingen, Germany) was layered on top of the reaction mixture and 2.5 units Taq DNA polymerase was then added. The reaction mixture was centrifuged at low speed. Conditions for PCR were as follows: $42^{\circ} \mathrm{C}$ for 60 minutes (for the primer specific reverse transcription), $95^{\circ} \mathrm{C}$ for five minutes (to denature the reverse transcriptase and to liquify the wax interface), then 15 cycles of $94^{\circ} \mathrm{C}$ for 15 seconds, $45^{\circ} \mathrm{C}$ for 15 seconds and $72^{\circ} \mathrm{C}$ for 15 seconds, followed by a 10 minute extension step at $72^{\circ} \mathrm{C}$. A "hot start" nested PCR utilising the HepCV 23 and HepCV 24 primers was then carried out as for conventional RT-PCR. After amplification, $10 \mu \mathrm{l}$ of the PCR products was run on a $1.5 \%$ agarose gel stained with ethidium bromide at 60 volts for 60 minutes and visualised under ultraviolet light.

RT-PCR OPTIMISATION, SPECIFICITY, SENSITIVITY AND QUALITY CONTROLS

RT-PCR was optimised as described by Roux. ${ }^{8}$ The inhibitory effects of reverse transcriptase on Taq DNA polymerase were assessed and the optimal ratio of reverse transcriptase to Taq DNA polymerase was determined. To determine the optimal amplification time required to ensure a sharp distinction between a positive and negative result, PCR was stopped after 15 , 30 and 60 cycles.

Specificity of the PCR products was confirmed by high stringency dot blot hybridisation using a 30 mer oligonucleotide (Alx-89 5'-CCA TAG TGG TCT GCG GAA CCG GTG AGT ACA-3') as described by Han et al. ${ }^{9}$ The oligonucleotide probe was non-radioactively, $3^{\prime}$ end labelled with digoxigenin (Boehringer Mannheim), according to the manufacturer's instructions. Hybridisation conditions and detection of digoxigenin labelled RNA were essentially as described by Canepari et al. ${ }^{10}$ Briefly, PCR aliquots were diluted with herring sperm DNA and transferred to a nylon membrane (Qiabran, Qiagen, Hilden, Germany). After fixation with ultraviolet light, the amplicons and probe were hybridised for $90 \mathrm{~min}$ utes at $54^{\circ} \mathrm{C}$. The melting temperature was 


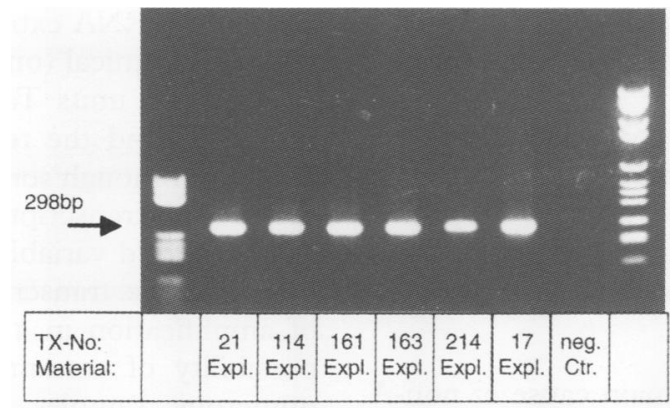

HCV RNA Detection in Liver Tissue "one tube" RT-PCR

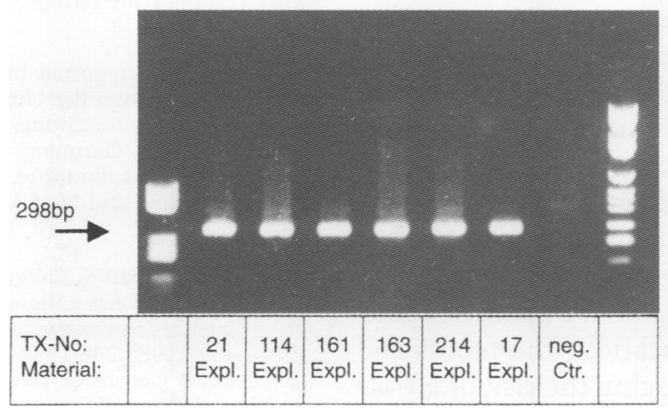

Figure 1 Comparison of conventional RT-PCR (top) and with combined RT-PCR (bottom) in which reverse transcriptase and Taq DNA polymerase were added in a common buffer. Lanes 1 and 9, DNA molecular markers $V$ and VI, respectively; lanes $2-7, H C V$ positive patients; lane $8, H C V$ negative patient.

estimated as suggested by Sambrook et al. ${ }^{11}$ Non-specific or unbound probe was removed by high stringency, post-hybridisation washes. After blocking the membrane, the hybridisation signal was detected using an alkaline phosphatase conjugated digoxigenin antibody and an alkaline phosphatase substrate solution consisting of nitroblue tetrazolium and 5-bromo4-chloro-3-indolylposphate. Serial dilutions of liver RNA were amplified by the nested PCR to test the sensitivity of the technique.

All samples were tested in duplicate and in parallel with negative controls. Only those samples with positive results in duplicate

Table 2 Determination of the optimal reverse transcriptase:Taq DNA polymerase ratio with constant amount of Taq DNA polymerase (2.5 units) in the combined RT-PCR (alternative 1): comparison of results with conventional RT-PCR

\begin{tabular}{|c|c|c|c|c|c|c|c|}
\hline & $\begin{array}{l}\text { Case } \\
\text { number }\end{array}$ & $\begin{array}{l}\text { Conventional } \\
R T-P C R\end{array}$ & Comb & ed $R T$ & ${ }^{\circ} \mathrm{CR}$ & & \\
\hline \multicolumn{2}{|l|}{ AMV reverse transcriptase units } & 500 & 0 & $6 \cdot 25$ & $7 \cdot 5$ & $12 \cdot 5$ & 500 \\
\hline \multicolumn{2}{|l|}{$\begin{array}{l}\text { Reverse transcriptase: Taq DNA } \\
\text { polymerase ratio }\end{array}$} & 200 & 0 & $2 \cdot 5$ & 3 & 50 & 200 \\
\hline \multirow[t]{19}{*}{ HCV-RNA positive liver tissue } & & $9 / 18$ & $0 / 18$ & $9 / 18$ & $9 / 18$ & $0 / 18$ & $0 / 18$ \\
\hline & 1 & + & - & + & + & - & - \\
\hline & 2 & - & - & - & - & - & - \\
\hline & 3 & + & - & + & + & - & - \\
\hline & 4 & - & - & - & - & - & - \\
\hline & 5 & - & - & - & - & - & - \\
\hline & 6 & + & - & + & + & - & - \\
\hline & 7 & - & - & - & - & - & - \\
\hline & 8 & - & - & - & - & - & - \\
\hline & 9 & - & - & - & - & - & - \\
\hline & 10 & - & - & - & - & - & - \\
\hline & 11 & + & - & + & + & - & - \\
\hline & 12 & - & - & - & - & - & - \\
\hline & 13 & - & - & - & - & - & - \\
\hline & 14 & + & - & + & + & - & - \\
\hline & 15 & + & - & + & + & - & - \\
\hline & 16 & + & - & + & + & - & - \\
\hline & 17 & + & - & + & + & - & - \\
\hline & 18 & + & - & + & + & - & - \\
\hline
\end{tabular}

samples were regarded as positive. The specificity of the nested PCR was assessed by the synthesis of cDNA without reverse transcriptase to exclude contamination of the PCR product and by a single step PCR using the same primer to exclude cross-contamination between the sense and antisense primers. The general measures suggested by Kwok and $\mathrm{Hi}$ guchi for avoiding false positive results were followed. ${ }^{12}$

\section{Results}

\section{PRELIMINARY STUDIES}

As the efficiency of the conversion of RNA to cDNA greatly influences the sensitivity of PCR, we first optimised reverse transcription of RNA. Using different amounts of total RNA, gene specific priming conditions for reverse transcription were examined so as to give maximum yield on amplification by PCR. We found that sensitivity was greatly influenced by the temperature and the amount of RNA and reverse transcriptase present. The best results in the conventional RT-PCR were obtained with 400 units of Superscript reverse transcriptase or 500 units of AMV reverse transcriptase and relatively high temperatures $\left(42^{\circ} \mathrm{C} v 37^{\circ} \mathrm{C}\right)$.

CONVENTIONAL RT-PCR AND COMBINED RT-PCR All specimens from the nine patients infected with HCV were positive on conventional RTPCR. Similarly, liver specimens from the nine patients without $\mathrm{HCV}$ infection were negative. The same results were obtained with combined RT-PCR in which mineral oil was used to overlay the reaction mixture (table 1 , fig 1). This, however, was only achieved if an optimal ratio between reverse transcriptase and Taq DNA polymerase of about 2.5:3 (table 2) was maintained. RT-PCR incorporating PrimeWax also yielded appropriate results in the 15 specimens tested (table 1). Three samples were not tested using this method.

\section{HCV Infection in Explanted Livers} Dot Blot Hybridisation (Alx 89)

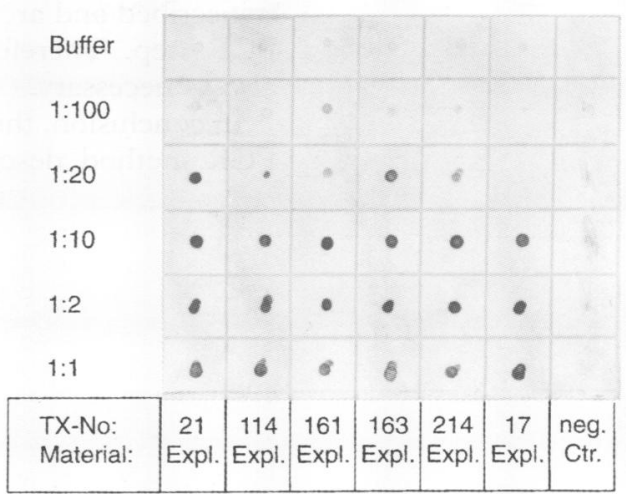

Figure 2 Dot blot assay, at several dilutions (indicated on the left), of the seven $298 \mathrm{bp}$ amplification products of HCV RNA, as shown in fig 1 , carried out by hybridisation with the digoxigenin labelled Alx-89 oligoprobe and visualised using an alkaline phosphatase anti-digoxigenin antibody and a suitable chromogen. 
SPECIFICITY AND SENSITIVITY ASSAYS

The results obtained with both conventional and combined PCR were confirmed by dot blot hybridisation (fig 2). As little as $500 \mathrm{ng}$ of total RNA was needed as the template to produce detectable amounts of cDNA on the agarose gels.

\section{Discussion}

Hepatitis $C$ virus is the main cause of non-A, non-B hepatitis and its high infectivity highlights the importance of detecting carriers and diagnosing infection early in its clinical course.

HCV RNA extracted from liver tissue can be detected using conventional RT-PCR. To avoid contamination we modified the conventional multistep PCR protocol and carried out all reactions in a single tube as a single step procedure. Two alternative procedures were tested: (1) the addition of reverse transcriptase and Taq DNA polymerase in a common buffer; and (2) separation of the enzymes by a wax interface. By combining cDNA synthesis and the first round of amplification, the technique is simplified, thereby reducing the risk of crosscontamination. To our knowledge, a simplified, optimised combined procedure for detecting HCV RNA has been reported for serum samples only. ${ }^{34}$

The specificity of our combined RT-PCR was confirmed by dot blot analysis. Although Taq and Thermus thermophilus DNA polymerases are reported to be able to transcribe RNA templates directly, ${ }^{1314}$ we have achieved positive results only when using AMV or Moloney's murine leukaemia virus reverse transcriptases (Boehringer Mannheim, Mannheim, Germany) to first transcribe RNA into cDNA templates for PCR. Attempts to couple reverse transcription and PCR have been twarted because of the thermolability of reverse transcriptase and because it can inactivate Taq DNA polymerase. However, when a reverse transcriptase:Taq DNA polymerase ratio of $2 \cdot 5: 3$ was strictly maintained, positive results were achieved using the combined RT-PCR procedure in which the enzymes were not separated by a wax interface. But, although gene priming reverse transcription is a highly efficient technique, non-specific products are often transcribed and are frequently amplified in the PCR step. Therefore, nested PCR is almost always necessary.

In conclusion, the single step, combined RTPCR method described herein is rapid (five hours from RNA extraction to RT-PCR products), economical (only 6.5-8 units AMV RTase and 2.5 units Taq DNA polymerase are required), and the results are consistent and reliable. Although some authors prefer to keep the reverse transcription and PCR steps separate to avoid variable cDNA synthesis, combining reverse transcription and the first round of amplification in a single tube reduces the possibility of contamination and may allow numerous samples to be processed simultaneously which, in turn, may facilitate automation. This method may also be useful for confirming the results of immunohistochemistry, in situ hybridisation or in situ PCR.

This work was supported by Forschungsschwerpunkt Transplantation, Klinikum der Universität Heidelberg. We thank Dr H Müller, Bundesforschungsanstalt für Viruserkrankungen der Tiere, Tübingen, Germany, who provided the HCV primers. The authors gratefully appreciate the technical assistence of Ms B Melz-Rothfuss and Mr J Moyers.

1 Saiki RK, Scharf S, Faloona F, Mullis KB, Horn GT, Erlich $\mathrm{HA}$ et al. Enzymatic amplification of $\beta$-globin genomic sequences and restriction site analysis of sickle cell anemia. sequences and restriction site
Science $1985 ; 230: 1350-4$.

2 Tilston P, Corbitt G. Detection of hepatitis C virus RNA in serum, by combining reverse transcription and polymerase chain reaction in one tube. 7 Virol Methods 1993;44:57-66.

3 Murakami S, Takahashi Y, Yoshida S, Fuke I, Ohmae K, Mori C, et al. Highly sensitive detection of viral RNA genomes in blood specimens by an optimized reverse transcription-polymerase chain reaction. $\mathcal{F}$ Med Virol 1994; 43:175-81

4 Takamizawa A, Mori C, Fuke I, Manabe S, Murakami S, Fujita J, et al. Structure and organization of the hepatitis $\mathrm{C}$ virus genome isolated from human carriers. $\mathcal{f}$ Virol 1991;65:1105-13.

5 Theilmann L, Solbach C, Toex U, Müller H, Pfaff E, Goeser T. Role of hepatitis C virus infection in German patients with fulminant and subacute hepatic failure. Eur $\mathcal{f}$ Clin Invest 1992;22:569-71.

6 Chomczynski P, Sacchi N. Single-step method of RNA isolation by acid guanidinium thiocyanate-phenol-chloroform extraction. Anal Biochem 1987;162:156-9.

7 Chou O, Russell M, Birch DE, Raymond J, Bloch W. Prevention of pre-PCR mis-priming and primer dimerisation improves low-copy-number amplifications. Nucleic Acids Res 1992;20:1717-23.

8 Roux KH. Optimization and troubleshooting in PCR. PCR Methods Appl 1995;4:S185-94.

9 Han JH, Shyamala V, Richman KH, Brauer MJ, Irvine B, Urdea MS, et al. Characterization of the terminal regions of hepatitis $C$ viral RNA: identification of conserved sequences in the $5^{\prime}$ untranslated region and poly(A) tails at quences in the $5^{\prime}$ untranslated region and poly(A) tails

10 Canepari P, Di Stefano CF, Leo MM. Rapid detection of PCR products of hepatitis C virus (HCV) with a nonradioactive oligoprobe. Microbiologica 1994;17:9-14.

11 Sambrook J, Fritsch EF, Maniatis T. Molecular cloning: a laboratory manual. 2nd edn. Cold Spring Harbor, New York: Cold Spring Harbor Laboratory Press, 1989.

12 Kwok S, Higuchi R. Avoiding false positives with PCR. Nature 1989;339:237-8.

13 Tse WT, Forget BG. Reverse transcription and direct amplification of cellular RNA transcripts by Taq polymerase. Gene 1990;88:293-6.

14 Myers TW, Gelfand DH. Reverse transcription and DNA amplification by a Thermus thermophilus DNA polymerase. Biochemistry 1991;30:7661-6. 